\title{
Tin Mining and the Formation of a New Local Shadow State: The Case of Lom People, Bangka Indonesia
}

\author{
Iskandar Zulkarnain $^{1 *} \quad$ Endriatmo Soetarto ${ }^{2}$ Satyawan Sunito ${ }^{2}$ Soeryo Adiwibowo ${ }^{2}$ \\ 1.Department of Sociology, University of Bangka Belitung, Bangka Belitung 33172, Indonesia \\ 2.Department of Communication Science and Community Development, Bogor Agricultural University, Jalan \\ Kamper Kampus IPB Dramaga, Bogor 16680, Indonesia
}

\begin{abstract}
Tin of Bangka has been exploited since the $18^{\text {th }}$ century. Exploitation throughout history has led to various debates over the subject on the right to access and control tin. After the New Order regime in 1998, the intensity of the controversy debates increased and escalated because the subjects were increasingly mapped, contested with a variety of interests, and creating a local "fallacious" state. Among the controversy debates, there is still room for another controversy. How could ethnic minorities called the Lom tribe which known as traditional, full of mysticism, believed to be conservationists, could be trapped into the economic turmoil of illegal tin mining? This article tries to prove that the Lom Tribe is not entirely in a dark matter. The practice of small-scale voluntary, massive and extensive tin mining in customary forest, accompanied by efforts to create counterterritories and claims for customary autonomy is a form of struggle to maintain the continuity of access/control over tin and resistance against the expansion of private oil palm plantations. This kind of practice marks the emergence of a new local shadow state in the lowest village governance structure.
\end{abstract}

Keywords: actor, counter-territory, resistance, shadow state, tin

DOI: $10.7176 /$ RHSS/9-4-02

\section{Introduction}

Customary communities as representations of small farmers cannot fully with stand agaist the flow of global change. Customary communities which long been known as guardians of collective pride (Li, 2010) and collective welfare guards (Warren, 2010) have been transformed towards a capitalist system. The phenomenon of customary communities in Ethiopia, Zambia, Philippines, Chile, and Ecuador are some countries that actually show social change due to intersect with capitalism. Transformation of customary communities in Zambia is caused by the commercialization of agriculture through capital investment supported by a set of state policies (Matenga and Hichaambwa, 2017), land grabs in Ethiopia (Lavers, 2012; Makki, 2012), forcing customary farmers to make choices, leaving subsistence or intensified farming systems as the contract farming system (Montefrio, 2017). Some of these examples mark the phenomenon of capitalism as a social relationship seeing how the emergence of capitalist production relations in the struggle for commodities and identity (Li, 2014) and the establishment of power relations over production methods that positions one party as dominant and the other as marginal (Darmanto, 2015).

The focus of this article is on contemporary research in Indonesia, primarily the case of customary communities that have some similarities with other countries such as the struggle for commodity access, commercialization of agriculture, and land grabbing. Transformation of customary community of Lom people Bangka mark changes in social relations. Lom people are actively involved in this transformation along with the presence of two commodities, namely tin and palm-oil. In 1998, based on changes to the Decree of the Minister of Industry and Trade Number 558/MPP/Kep/12/1998 which essentially did not include tin as goods which were regulated and supervised in exports (Indra, 2014). This decision has lead implications that tin becomes free goods for anyone. This opportunity was used by Lom People in Air Abik to access tin illegally on land claimed as customary land. The spirit of Lom people in mining tin led them to the arena of competition by actively utilizing market opportunities and attaching themselves to a new culture that is admiring a consumptive lifestyle.

The presence of an oil palm plantation company owned by PT Gunung Pelawan Lestari (PT GPL) after obtaining a location permit from the Bangka Regent in 2004, based on Decree Number 188.45/349/SKIL/I$\mathrm{TNH} / 2004$, posed a new threat to tin's economic sustainability. For Lom people the tin economy was welcomed enthusiastically as a way out from the ongoing traditional-mining activities and was considered a way out from poverty. The palm oil economy creates resistance from Lom people because it is considered to damage the landscape extensively for a long term. The change in the landscape of land ownership from communal to private is a threat that needs to be anticipated. This study will offer the first step in identifying literary gaps that may require further investigation.

Some previous researchers found relevant findings to this study. The study of the practices of small-scale mining and inland resources is a form of transition between the two strategic commodities which seen as manifestation of capitalist production relations in the same space (De Angelis, 2004; Barney, 2009; Peluso and Lund, 2011; Hall, 2011, 2013; Kelly and Peluso, 2015; Peluso, 2017). This practice is the result of the 
intervention of state institutions involved in issuing a number of regulations and policies that actually show the power of monopoly access and formal territory (Lund and Boone, 2013; Elden, 2009; Petkova, Lockie, Ivanova, 2014; Petkova and Marinova, 2013; Vandergess and Peluso, 1995 ) In other cases it creates the informal territory (Peluso, 2017) the informal economy (Verbrugge, 2015; Sikor and Lund, 2009; Lund, 2006; Duus, 2013), "inland constellation" (Eilenberg, 2016), and shadow states (Reno, 1995; Hilson, 2013; Tschakart, 2009).

In Indonesia, the practice of small-scale mining raises the term "local shadow state" (Erman, 2007; Spiegel, 2012), "informal territory" (Peluso, 2018), and "informal economy" (Hidayat, 2007; Lestari, 2007, 2013). The practice of small-scale tin mining that operates massively and extensively by involving actors from state institutions at the local level in the informal economy, as a continuation of the practice of the New Order regime read as an effort to develop a 'local shadow state' (Erman, 2007). The practice illustrate how informal behavior takes place to make a profit by being involved in a tin business mafia. This picture shows the close relationship between the state and the market, bureaucrats and business people in the legal and illegal economy who seem to be in the blurred-shade. The essence of the "local shadow state" shows that a country that is considered an agent of comprehensive and just development has failed to carry out its obligations properly since the New Order to regional autonomy. The failure of the state is due to the fact that the official state is still captured by 'informal regulators' who are based on tin businessmen and their cronies in various ways, often with violence.

\section{Research Method}

Qualitative research on case studies was chosen as the right method based on several reasons. First, the strength of case studies lies in micro-level studies (Sitorus 1998). Micro-level studies can highlight one case specifically and deeply (intrinsically), a special case for improving theory (instrumental), or a number of cases that are similar or mutually different together to learn a symptom (collectively). The instrumental case studies were selected in addition to being used to assist researchers in understanding a particular problem also used as an effort to improve the theory. Second, case studies demand separate time tracking (Yin 2013). Not limited to the scope of classical history but in the scope of contemporary history which some of the perpetrators are still alive. Therefore, this research is focused on the history of the social economic relations of tin and the dynamics of actors contestation in the tin production space. Third, the case study is a multi-method research strategy. Methods of observation, interviews, focus group discussions, and document analysis were used by researchers in supporting case studies.

This research is located in Gunung Muda Village (see figure 1) and specifically in Air Abik Hamlet, Belinyu District, Bangka Regency, Province of Bangka Belitung Islands, Indonesia (see figure 2). There are three basic reasons why Hamlet Air Abik was chosen as a research location. First, this hamlet is a home of the customary Lom people of Bangka until now. Second, this hamlet is an area affected by tin mining exploration and exploitation (PT Timah's IUP area). Third, this hamlet is the latest and last locus for PT GPL's oil palm plantation expansion after a prolonged tenure conflict.

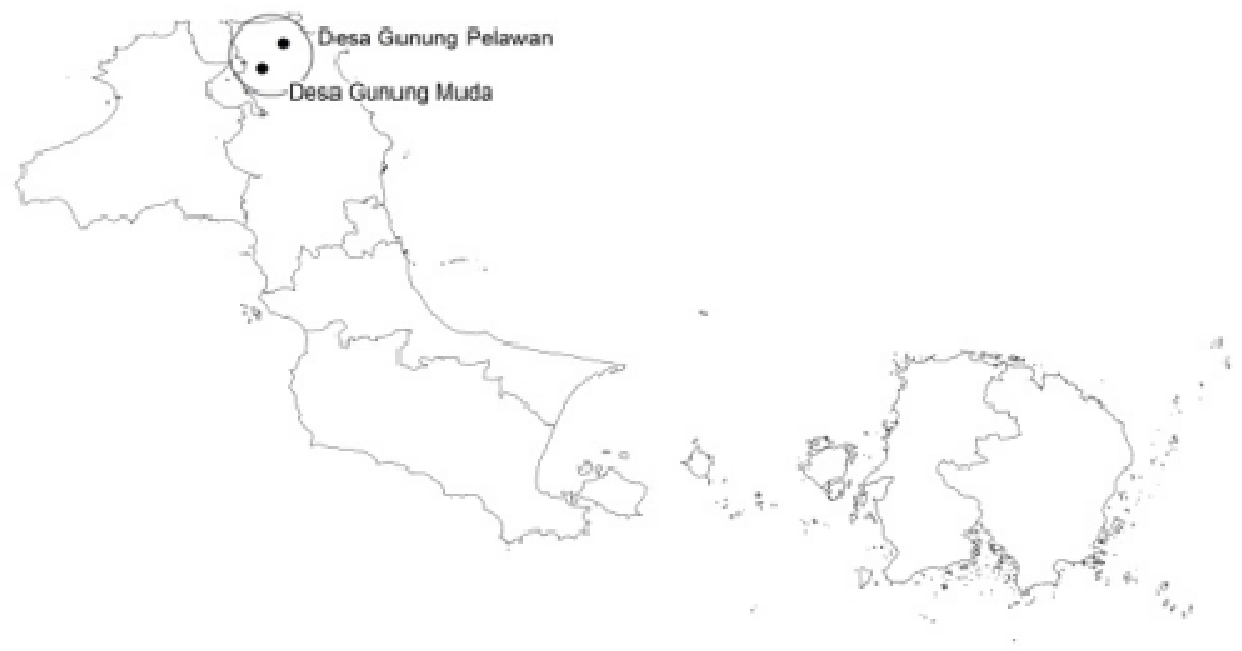

Figure 1. Map of Gunung Muda Village, Belinyu District, Bangka Regency 


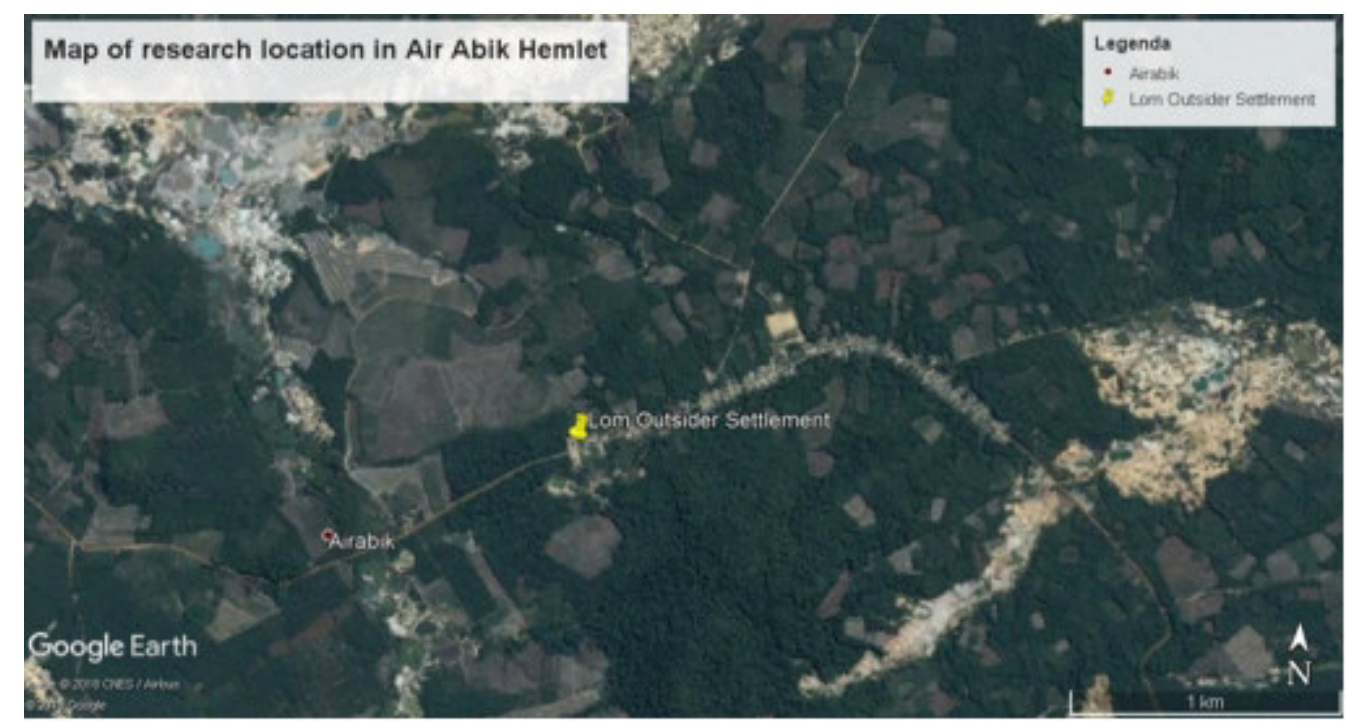

Figure 2. Map of research location in Air Abik Hamlet

Data collection began on April 2018 to September 2018. Data was collected through two techniques, namely primary data collection and secondary data. Primary data is obtained through group discussions, interviews, and participant observation. Group discussions are conducted at the hamlet level to understand the history of shifting process from farming fields to mining tin and the socio-economic relations that shape it. As many as nine people involved in the group discussion consisted of custom leaders and traditional figures of the Lom People. The important question asked was whether Lom People were involved in illegally panning tin in customary forests? Why was the activity carried out and how was the activity carried out? Through group discussion macro information about change can be used to reconstruct the interview's question guide.

Interviews were conducted with twenty seven key informants consisting of former customary leaders, elders of Lom people, illegal tin miners, and Head of Hamlet of Air Abik as well as respected figures. Questions about who was the actor who once illegally panned tin in customary forests during the New Order (1967-1998) were rather difficult to trace in group discussions. This question was extracted from key informants and began to reveal who the actors were. The snowball strategy is used and adequate to help researchers to explore information about the actors involved and the dynamics of contestation. The results of the interview found one unique thing regarding the management of the 'cash box' policy that was used by the Head of Air Abik Hamlet as a safety valve for solidarity among customary people in Air Abik. Participant Observation is used to directly see and experience the tin mining activities and behaviors that Lom People shown. The secondary data was obtained through documentation studies in the form of news that included the action of refusal of customary people of Air Abik, Bangka Regent's decree regarding the location permit and establishment of PT GPL, and the results of the research in the form of books and journals.

Data analysis is done qualitatively through an interactive analysis model. In analyzing qualitative data, primary data and secondary data are carried out simultaneously, namely data reduction, data presentation, and conclusion through verification (Miles and Huberman, 1994). The first stage, data reduction is the stage of the process of selecting, simplifying, abstracting and transforming rough data generated from field. The second stage is the presentation of data in the form of quotations of research statements, tables, images that are not presented in the form of raw writing, but analyzed, linked, and synthesized to produce a form of interpretation of the data (Sitorus, 1998). The third stage, the stage of taking conclusions. Descriptive qualitative data that has been analyzed and synthesized into a form of critical interpretation then concluded to answer the problem statement.

\section{Results and Analysis}

\subsection{Lom People: Minority Ethnic and Social Relations}

The Mapur Lom tribe is a minority ethnic in Bangka Island. Minority ethnic are characterized by their small population, narrow geography, and socially has lesser-economy conditions. According to Olaf H Smedal, in the early 1980s, Lom people had a population of around 750 people. In 2007 their number has increased to 1,200 (Smedal, 2018). This Smedal record might refer to the Lom population in two locations namely Air Abik and Pejam. In 2014 the population of Lom in Air Abik was around 280 people (Zulkarnain and Franto, 2014). There are difficulties in ensuring the population of Lom in Air Abik considering that some of them live in the inner area of the forest, have the habit of shifting-agriculture, some others live in settlements and live side by side with newcomers. The total population in 2014 and the composition of religious adherents can be seen in Figure 3. 
Minorities from the social aspect, Lom people often get negative treatment in the form of social exclusion from residents around the settlement (Cholillah, 2015), discriminatory policies in demographic services (Sulaiman, 2014) and recognition on beliefs or religions that led to a split personality (Janawi, 2015). In the aspect of public service, it shows that quality health social security such as facilities and infrastructure is inadequate and no guarantees of recognition of customary law (Ristian and Suranto, 2014). As such, Lom people is clearly not among the ethnic groups in Indonesia with a majority status.

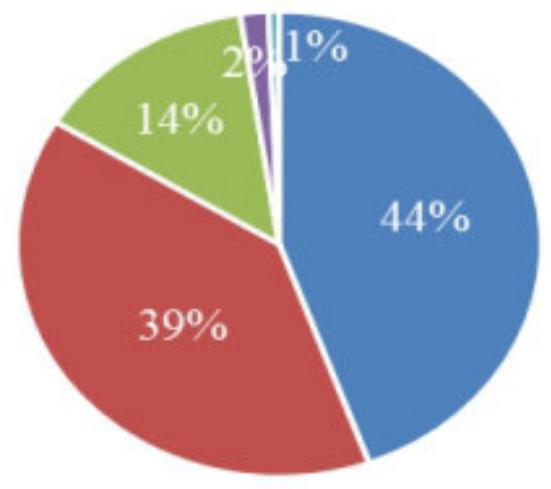

\author{
- Orang lom \\ - Islam \\ - Christian \\ - Konghucu \\ - Buddisme
}

Figure 3. The composition of religious adherents in Air Abik Hemlet

Though received this treatment in social life, Lom people continue to survive from exclusion and discrimination. Interaction with Chinese ethnic is one of the strategies taken to survive. Socially, the relationship between the two ethnics is tied to the historical similarity in which Chinese ethnic was working as tin labors (Sujitno, 2007; Erman, 2009) and Lom people was working as labors in Chinese ethnic's own mines. Economically, relation in trade activities form the basic spirit of the partnership whose core is "business management for economic prosperity on the basis of togetherness" (Sujitno, 2007). This association spirit was what lied behind the rampant smuggling of tin sand by Chinese ethnic to Singapore since the New Order, especially in the 1970s and the practice of illegal tin mining by Lom people around the 1990s.

In an effort to anticipate the activity of smuggling tin sand and illegal tin mining, PT Timah Tbk, as a stateowned enterprise, has implemented a tin mining policy with a contract scheme called Tambang Karya (TK). The TK mine is a mining activity for small-scale less productive areas whose results must be delivered to PT Timah (Sujitno, 2007). The majority of TK owners and operators are Chinese ethnics. The TK structure includes PT Timah as the power holder who authorized to transfer right on mining to the private sector, TK owners who are often called "cukong" ("boss", from Chinese ethnic), foremen as TK mining technical representatives, and waged-labor which has functional job suitable for mining purposes. Lom people works as laborers in "cukong's" TK. Their main task as a guard and cleaner of "sakan" (a place to collect sand mixed with tin), "sakan" sprayers, separate and clean sand and tin ores, and put tin ores into sacks.

An important point from the involvement of Lom People in the TK mining structure is the transfer of tin mining technology from "cukong" and field foreman. Knowledge to identify location contain tin ores, equipment requirements, tin mining methods, technical operation of machinery, and all mining equipment, can be controlled by Lom people. From the knowledge and experience of mining tin, it became the provision of the Lom people in mining tin unconventionally after the New Order, especially at the beginning of the 2000's. In addition, Lom people also get weekly wages from working in TK mines. The wages received are the beginning of their contact with money as a means of universal exchange.

\title{
3.2 Dark Matter of Lom People and Counter-Territory
}

Post-New Order was the most controversial period in Air Abik due to the involvement of Lom People in TI mining activities in 'customary forests'. This practice is referred as a dark matter, because TI mining by Lom people in the customary forest involves new actors, new ways and interests. The appearance of the actor named Taktui, the Hamlet Chief as well as a respected figure of Lom people, in the dynamics of contestation over the struggle for access and control over tin resources. In more detail, the following description of the case will explain how Taktui's role and the struggle to gain access and how the space of territorialization process took place.

Case 1

In March 2003, after the issuance of the Bangka Regent decree, there were more than 164 "camui" holes in the Lom people customary forest area in Air Abik north of Belinyu (See Smedal, 2018). Some miners look excited 
towards the TI mine. After obtaining an TI location covering an area of approximately 2 hectares, without a permit (official) process, it was enough to get approval from the Hamlet Chief as well as a community leader named Taktui. They rent excavators or bulldozers to open land that takes two days. Heavy equipment was obtained from renting to Taktui which obtained loans of 6 units of heavy equipment from cukong or tin bosses from ethnic Chinese.

By renting to Taktui, all technical needs are met. Starting from deciding location and permit, supply of diesel fuel, and heavy equipment can be obtained. Every mining operator (bulldozer) has to pay an operation fee of around USD 10 (Rp. 100,000) every month and TI miners have to pay heavy equipment rental costs of around USD 2 dollars (Rp. 20,000) per hour/day. Estimated in 2003, the cost of renting heavy equipment from 164 "camui" collected nearly USD 20,000 throughout the year. For what purpose are these funds?

Taktui wants to implement a wise political move by being able to create a 'settlement cash-box' (see Smedal, 2018) where available money is used for certain special purposes such as the annual feast "nujuh jerami" and hamlet cash tactical funds used for residents of Air Abik who need emergency financing such as accidents,maternity, or surgery. The 'settlement cash box' is a kind of pride for the residents of Air Abik. Tagtui also takes $10 \%$ of the operational costs of bulldozers and excavators for its own purposes. Apart from tin, Taktui also collects fees from logging collectively in customary forests.

In 2007 , the population of the Lom people grew from 750 people to 1200 people. A contrasting scene can be seen from changes in the shape of houses from the beginning of government assistance (isolated tribal projects) to being relatively new and rich. Vehicle ownership has increased, especially motorbikes, some households have managed to buy pickups, even trucks, television sets, DVD players/satellite TV, and almost every home has a gasoline-powered generator for household electricity supply.

Case 2

Year 2005 was the beginning of a controversy for customary Lom residents. An agribusiness company operated in oil palm plantation sector based in the UK present under the name of PT Gunung Pelawan Lestari (PT GPL). PT GPL began to develop plantations in northern Bangka, mostly covering the customary areas of Lom Air Abik. The project received a concession permit of around 12,000 hectares which will be planted with oil palm using plasma scheme. Plasma under the local village farmers cooperative which will manage around 5000 hectares. A palm oil mill will be built to process the fruit, both from the plasma crop and from the surrounding oil palm farmers.

The existence of PT GPL through the palm plasma program was opposed by some of the customary Lom residents in Air Abik. The main reason is the palm oil will threaten the preservation of customary forests. Another reason is the concern of most Lom people about debt if incorporated into the plasma scheme. The resistance was inflated. Year 2013 and 2014 were the beginning of the biggest and coordinated action. Taktui is a central figure.

The most heroic protests to refuse existence of PT GPL occurs when PT GPL allegedly encroached the Lom customary grave in Air Abik in April 2014. News of the destruction of customary graves by PT GPL's bulldozers extended to the national level. About seven national medias and almost all local media highlight this issue. From here the actions to various parties such as the Bangka regent's office, the Bangka parliament (DPRD) to hearings with National Parliament (DPR) and the National Human Rights Commission (Komnas HAM) in Jakarta continued. The refusal action also involved NGOs such as Friend of the Earth (WALHI) and Bangka Belitung Legal Aid Institute (LBH) in advocacy. Where did the action fund come from?

On the interesting side, almost all the technical needs of action and rejection were supplied from hamlet tactical funds originating from the results of heavy equipment rental and Tagtui's personal fund as well as the 'fallacious' network. In 2014 the cash to almost IDR 60 million was spent for action purposes, hearings to the country's capital, and pay advocate services. Transparency in the expense of funds was hardly well reported.

At least two important points can be drawn from the two cases above. The first point, 'settlement cash-box' needs to be seen as the process of forming territory. Foresight of the Lom people at the grassroots level in utilizing the opportunities for deregulation of the tin trade system, marks the end of the power of formal access and control by the state to tin resources. The power of access and territorial control over tin resources seems to belong to anyone. It means, everyone has the right to open a location, mine TI as long as supported by adequate funds. Practices like this led the emergence of informal territory.

Utilizing the opportunity of open access from ongoing informal territories, Lom people voluntarily cleared land and mined TI on family-owned (hereditary) land claimed to be 'customary land'. In the beginning, TI mining only involving small groups consisting of family member of 2-5 people depending on the area of land mined. As income from TI increases, the number of miners is increasing rapidly. Migrants living in Air Abik are involved in TI mining. As a result, TI mining practices run un-controlled and without real contributions to the local population. This condition encourages Taktui's involvement in regulating and controlling TI mining at Air Abik. With three capabilities, namely the power of knowledge (the complexity of administration/licensing/spatial planning of customary land), mastery of networks in tin mining, and the ability 
to mobilize tin actors in Air Abik and the surrounding area. These three capabilities are used by Taktui to accommodate the expectation of TI miners at Air Abik.

The second point is how the ' settlement cash-box ' has increased its function as an instrument to resist the expansion of PT GPL's oil palm plantation company. Taktui and his group and residents made the Lom customary forest a shield by giving rise to a customary autonomy discourse. Customary forest territories are mapped, formed, and used for the benefit of farming, pepper cultivation, and preserving rare flora and fauna. In addition, traditional rituals such as "nambek kubur", marriage ceremonies and funeral as well as customary Lom traditional arts continue to be intensified. Customary institutions are formed and confirmed through the decision of the hamlet chief. The tradition of using traditional herbs from Lom's customary forests is also strengthened.

The customary autonomy discourse which was initiated by Taktui proved to be quite successful. All Lom people and other residents of Air Abik unite to form a social force rejecting the presence of PT GPL. Citizen fully support Taktui comprehensively. The results of the 2014 survey data showed that 60 percent of Lom's customary people wanted the issuance of village regulations for the protection and management of customary territories initiated by village/hamlet governments (Zulkarnain and Franto, 2014). The survey results can be seen in Figure 4.

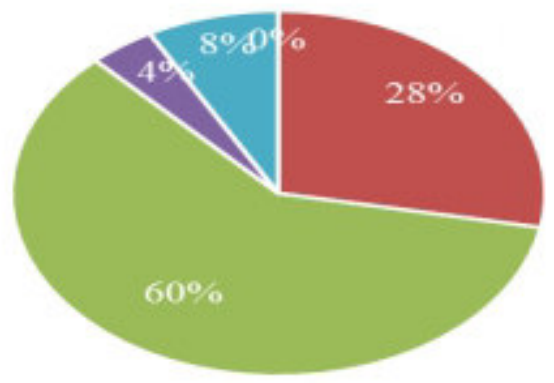

\author{
- Village government \\ - Custom society \\ = Chief of village \\ - Custom Institution \\ = don't know
}

Figure 4. Result of survey on effectivity of actors on water management in Air Abik (Zulkarnain and Franto, 2014, unpublished)

The discourse of customary forests and the struggle for customary autonomy that Taktui echoed had an impact on the emergence of fanatical support groups. Support groups came from Lom people, Chinese, Bataknese, and South Sumatran's Malay. Each group has a different role, but has the same interest of making customary forests as autonomous regions that researchers refer to as counter-territories. Counter-territories as an effort to protect land/forests, labor, and other sources of the commodification process. Thus, tin in Air Abik can only be exploited by residents of Air Abik. The same thing applied on wood. On the other hand, naming customary forests as autonomous regions in frame to fight the expansion of PT GPL's oil palm companies. PT GPL started working on land to plant oil palm since 2005. Anticipating the expansion of plantations, Tagtui and the residents of Air Abik took refusal actions from 2009 to 2015. The resistance to the existence of PT GPL peaked in 2014 when the Lom people's customary graveyard was damaged by PT GPL's heavy equipment which is operating around Air Abik. The discourse of the struggle for customary autonomy of the Lom people continues to be echoed.

The practice of Lom-style counter-territorialization led by Taktui and his group marks the emergence of a new local shadow state. The term local shadow state is a form of collaborative practice of various actors from state institutions at the local level in the informal economy (Erman 2007). According to Erwiza Erman, there are three main actors involved in carrying out the informal economy at the local level. First, bureaucrats and politicians who have access to power to give permission, protection, make and ratify regulations. Second, business groups that have capital but do not have direct access to power. Third, community groups that have certain goals to gain access and objects from the interests of various actors such as bureaucrats, politicians, and business people.

At least there are three reasons behind the emergence of the local shadow state in Air Abik. First, the involvement of an actor named Taktui in TI mining practices that exercised multiple authorities. He combines authority as a hamlet head and as a 'customary' figure which often overlaps. It is mean there is no clear boundary when to use authority as a hamlet leader or as a customary figure. Uniquely, the blurred boundary of authority is used to construct the popularity that only he can be trusted and able to solve all problems at Air Abik. Legitimacy is the goal of his actions. In contrast to the practices of the old tin business regime, everything was centralized under the authority of the Bangka regent.

Second, Taktui positions himself as a transitional actor as well as an intermediary actor. Transitional actors refer to three dimensions, namely time, space, and interest. The intermediary actor refers to the dimensions of capital ownership and cooperation in a particular social space. As a transition actor, Tagtui does not contest the state. He follows the rules of the game made by the state through PT Timah Tbk. The practice of TI mining in 
customary forests is not a form of non-compliance against PT Timah Tbk. but is interpreted as a step to secure territory and efforts to resist land grabbing by PT GPL. Directly, Taktui actually contested with private non-tin (PT GPL) in the expansion of oil palm plantations.

Taktui's presence as a transitional actor took advantage of the opportunity for social inequality. Social inequality is marked by how much control over the resources of power. Taktui has a number of abilities and knowledge such as knowledge of administration, spatial planning, and tin mining, which in its legitimate structure get moral, social and ideas power. As an intermediary actor, he has extensive social, economic and political access related to the tin network and closeness to traditional leaders of Lom. He gained moral economic, political, social and even supranatural power in his legitimation structure. The intersection between interests as transitional actors and intermediary actors leads to the formation of a 'settlement cash box '.

Taktui's ability to play the rhythm of the 'cash-box settlement' as the pride of Air Abik residents in the midst of differentiation of economic interests, has made him a safety valve. Taktui is considered to play a role as savior of the residents of Air Abik from the threat of poverty and economic difficulties (by accommodating TI) on the one hand, and on the other as a savior from the threat of PT GPL's expansion. The ultimate goal is to continue the exploitation of tin in Air Abik to ensure the spirit of shared-economy. In this context, Tagtui wants to say that he is a person who is responsible for himself as well as others. Using the opinion of Gramsci, that everyone in his social entity is an actor. Inter-actor connectivity always runs on the foundation of "actor act" and is always returned on that responsibility.

The third argument, as a responsible actor, Taktui uses the power of his authority to evoke the Lom customary autonomy discourse as an effort to maintain access and territory (customary and tin) from PT GPL's expansion. Taktui mobilized the masses and assembled customary figures from Lom and religious figures to reject the existence of PT GPL in Air Abik. Refusal actions started from blocking the pace of operations of PT GPL's heavy equipment, physical confrontation, to negotiation and advocacy channels at the district level to the central level. The discourse of customary autonomy has indirectly formed a counter-territory, as an effort to protect resources (land and tin mining) from the commodification process on the one hand, on the other as an effort to resist the expansion of PT GPL.

\section{Conclusion}

There are at least two points that can be concluded from this paper. The first conclusion, originated from the history of tin which made Lom people connected to the activity of illegal tin panning and smuggling of tin in the inner land. The New Order regime formed them to depend on the socio-economic conditions as the former labors of Chinese. In the "cukong"-style partnership, Lom people was more deeply involved in the dark matter as a weekly mine-labor. Indeed, by the "cukongs", Lom people are introduced to cash.

The second conclusion, entering the era of regional autonomy, deregulation of the trade system of tin dramatically changed, as well as the spirit of competing or hunting cash quickly and practically increasing. Most of them choose to mine TI. The extent of exploited customary forest land is increasing. Land deal for prospective new locations for TI mining is increasingly difficult to control. The Lom people were introduced to the 'settlement cash-box' as a symbol of their own pride as citizens of Air Abik. 'Settlement cash-box' increases the spirit of competition to maintain access to tin. Counter-territories and claims for customary autonomy were made justification for the resistance to the expansion of oil palm plantation companies.

The practice of counter-territories, 'settlements cash-box' and claims for customary autonomy were continuously reproduced from 2003 to 2015. All took place under the control of Taktui, a hamlet head in Air Abik as well as a customary figure who was followed by Lom people. With the power of knowledge (domination), representation (legitimacy), and social networking, he appears as a transitional actor as well as an intermediary actor. Practices like this mark the emergence of a new local shadow state marked by the emergence of new actors who are more specific from the local population (customary), using authority and legitimacy (spiritual) that often overlap for shared-economic interests (tin), using methods new counter-territorial claims and customary autonomy, as well as utilizing local government policies and the involvement of state actors at the local level in the informal economy.

\section{References}

Barney, K. 2009. Laos and the making of a 'relational' resource frontier. Geographical Journal 175, no. 2: 14659.

Brent, WZ. 2015. Territorial Restructing and Resistance in Argentina. The Journal of Peasant Studies 42:3-4, 671-694.

Cholillah, J. 2015. Orang Lom: Masalah Sosial dan Ancaman Kearifan Lokal Dalam Tinjauan Sosiologi. Society, Vol.1, No.2, 1-14.

Darmanto, 2015. Kapitalisme Pedalaman dan Praktik Politik Etnografi. Bhumi Vol. 1, No. 1, Mei 2015, 113-116.

De Angelis, M. 2004. Separating the doing and the deed: Capital and the continuous character of enclosures. 
Historical Materialism 12, no. 2: 57-87.

Duus, S. 2013. Coal Contestations: Learning form a long, broad view. Rural Society, 22 (2): 96-110.

Elden, S. 2009. Terror and territory: The spatial extent of sovereignty. Minneapolis: University of Minnesota Press.

Eilenberg, M, 2016. A State of Fragmentation: Enacting Sovereignty and Citizenship at the Edge of the Indonesian State. International Institute of Social Studies Development and Change Vol.47, No. 6, 13381360 .

Erman, E. 2007. Deregulasi Tata Niaga Timah dan Pembuatan Negara Bayangan Lokal: Studi Kasus Bangka. Politik Lokal di Indonesia, Nordholt dan Klinken, ed, Jakarta Yayasan Obor Indonesia-KITLV.

Erman, E. 2009. Menguak Sejarah Timah Bangka Belitung Dari Pembentukan Kampung ke Perkara Gelap, Yogyakarta Penerbit Ombak.

Hall, D. 2011. Land grabs, land control, and Southeast Asian crop booms. Journal of Peasant Studies 38, no. 4: $837-57$.

Hidayat, S. 2007. 'Shadow State'? Business and politics in the Province of Banten. InH. Schulte-Nordholt \& G. Van Klinken (Eds.), Renegotiating boundaries; Local politics in post-Suharto Indonesia. Leiden: KITLV Press, 238.

Hilson, G. 2013. Creating rural informality: The case of artisanal mining in subsaharan Africa. SAIS Review of International Affairs, 33(1), 51-64.

Janawi, 2015. Agama Adat Suku Mapur Bangka: Studi tentang Sistem Kepercayaan dan Budaya Orang Lom. Disertasi Pascasarjana UIN Kalijaga Yogyakarta.

Kelly, A., and N.L. Peluso. 2015. Frontiers of commodification: State lands and their formalization. Society and Natural Resources 28, no. 5: 473-95.

Lahiri-Dutt, K. 2004. Informality in mineral resource management in Asia: Raising questions relating to community economies and sustainable development. Natural Resources Forum 28, no. 2: 123-32.

Lestari, N. I. 2007. Illegal gold mining in West Java - Can Antam's community development programs win over cynical locals? Artisanal and small-scale mining in asia-pacific case study series. http://www.asmasiapacific.org.

Lestari, N. I. 2013. Mineral governance, conflicts and rights: Case studies on the informal mining of gold, tin, coal in Indonesia. Bulletin of Indonesian Economic Studies, 49 (2), 239-240.

Li, T.M. 2010. Adat di Sulawesi Tengah: penerapan kontemporer. Dalam Davidson, S.J, Henley D, Moniaga.S (Penyunting), Adat Dalam Politik di Indonesia. Jakarta: Yayasan Obor Indonesia dan KITLV Jakarta.

Li, TM, 2005. Transforming the Indonesian uplands: marginality, power and production. London, Taylor and Francise e-library, 14-71.

Lucas, A., and C. Warren. 2013. Land for the people: The state and agrarian conflict in Indonesia. Athens, OH: Ohio University Press.

Lund, C., \& Boone, C. 2013. Introduction: Land politics in Africa-Constituting authority over territory, property and persons. Africa, 83(1), 1-13.

Lund, Christian. 2006. Twilight institutions. Public authority and local politics in Africa. Development and Change, 37(4), 685-705.

Maconachie, R., and T. Binns. 2007. "Farming miners" or "mining farmers"?: Diamond mining and rural development in post-conflict Sierra Leone. Journal of Rural Studies 23: 367-80.

Makki, F. 2012. Power and Property: Commercialization, Enclosures, and the Transformation of Agrarian Relations in Ethiopia. The Journal of Peasant Studies Vol. 39, No. 1, 81-104.

Montefrio, JMF. 2017. Land Control Dynamics and Social-ecological Transformations in Upland Philippines. The Journal of Peasant Studies, Vol. 44, No. 4, 796-816.

Peluso, NL. 2018. Entangled Territories in Small-Scale Gold Mining Frontiers: Labor Practices, Property, and Secrets in Indonesian Gold Country. World Development Journal 101, 400-416.

Peluso, NL. 2017. Plantations and Mines: Resource Frontiers and the Politics of the Smallholder Slot. The Journal of Peasant Studies, Vol. 44, No. 4, 834-869.

Peluso, NL., and Lund, C. 2011. New frontier of land control: Introduction. The Journal of Peasant Studies, Vol. 38 , No.4, 667-681.

Petkova V., Lockie S., Ivanova G. 2014. Mining Development and Social Impact on Communities: Bowen Basin Case Studies. Rural Society, 19:3 211-228.

Petkova V., Marinova D. 2013. Social Impact of Mining: Change within local social lanscape. Rural Society, 22 (2): $153-165$.

Ristian A.,dan Suranto, 2014. Kualitas Pelayanan Publik pada Komunitas Adat: Studi Kasus Komunitas Lom di Kabupaten Bangka tahun 2012-2013. Jurnal Ilmu Pemerintahan dan Kebijakan Publik, Vol. 1, No. 2, 257 291.

Sikor, T., \& Lund, C. 2009. Access and property: A question of power and authority. Development and Change, 
$40(1), 1-22$

Sitorus, F, 1998. Penelitian Kualitatif Suatu Perkenalan. Bogor, Fakultas Pertanian IPB, 1998.

Smedal, O.H. 1989. Order and Difference: An Ethnographic Study of Orang Lom of Bangka, West Indonesia, Departement of Social Anthropology, University of Oslo (www.anthrobase. com)

Smedal, O.H, 2018. Resistence as a Problem An ethnic minority and the state in twenty-first century Indonesia. State, Resistance,Ttansformatioan Anthropological Perspectives on the Dynamics of Power in Contemporary Global Realities (Ed. Bruce Kaffer). London, Sean Kingstone Publising.

Spiegel, S. 2012. Governance institutions, resource rights regimes, and the informal mining sector: Regulatory complexities in Indonesia. World Development, 40(1), 189-205.

Sujitno, S. 2007. Dampak Kehadiran Timah Indonesia Sepanjang Sejarah. Jakarta, Cempaka Publishing.

Sujitno, S. 2007. Sejarah Penambangan Timah di Indonesia Abad 18-Abad 20. Jakarta, Cempaka Publishing.

Sulaiman A, 2014. Strategi Bertahan (Survival Strategy): Studi tentang "Agama Adat" Orang Lom di Dusun Pejem Belinyu Bangka, Provinsi Kepulauan Bangka Belitung. Jurnal Society, Volume II, Nomor 1, 1-14.

Tschakart, P. 2009. Digging deep for justice: A radical re-imagination of the artisanal gold mining sector in Ghana. Antipode, 41(4), 706-740.

Vandergeest P and Peluso NL. 1995. "Territorialization and State Power in Thailand." Theory \& Society 24 (3), $385-426$.

Verbrugge, B. 2015. The economic logic of persistent informality: Artisanal and small-scale mining in the Southern Philippines. Development and Change, 46(5), 1023-1046.

Warren, C. 2010. Adat dalam politik dan wacana orang Bali: Memosisikan prinsip kewargaan dan kesejahteraan bersama (Commonweal). Dalam Davidson, S.J, Henley D, Moniaga.S (Penyunting), Adat Dalam Politik di Indonesia. Jakarta: Yayasan Obor Indonesia dan KITLV Jakarta.

Yin, RK. 2013. Studi Kasus Desain dan Metode. Jakarta, Rajawali Pres.

Zulkarnain, I., dan Franto. 2014. Pemberdayaan Masyarakat Melalui Pemetaan Partisipatif Untuk Identifikasi dan Pemetaan Wilayah Adat Suku Lom di Kecamatan Belinyu Kabupaten Bangka, Jurnal Pengabdian kepada Masyarakat, Vol. 1 No.1, 9-17. 